\title{
EFEKTIFITAS EKSTRAK ETANOL KULIT NANAS (Ananas Comosus L. Merr) terhadap Trichophyton mentaghrophytes
}

\author{
Siti Juariah ${ }^{1)}$ Mega Pratiwi Irawan ${ }^{2)}$ Yuliana ${ }^{3)}$ \\ 1,2,3) Akademi Analis Kesehatan Yayasan Fajar Pekanbaru \\ Jl. Riau Ujung no. 73 Pekanbaru, Riau \\ email : sitijuariah@univrab.ac.id
}

\begin{abstract}
Ringworm of the skin caused by a Trichophyton mentaghrophytes, Drugs that are commonly used are synthetic drugs, synthetic drugs can have a negative impact. By because it, research on natural antifungal substances continue to do that with the use of pineapple skin. A pineapple skin waste processed pineapple industry, namely the remainder of the meat and fruit contains secondary metabolites are flavonoids, phenolics, saponins, triterpenoids, steroids and alkaloids. The purpose of this study to determine the content of secondary metabolites contained in the pineapple skin and for the inhibition of Trichophyton mentaghrophytes using experimental laboratoryin vitro. Pineapple bark extract prepared in various concentrations of $10 \%, 15 \%, 20 \%$ and $25 \%$, then test the inhibition of Trichophyton mentaghrophytesand incubated temperature 25o C for 5day. Based on the results obtained percentage pineapple skin extractfungal inhibition test Trichophyton mentaghrophytesthe concentration 10\%, 15\%, 20\% and 25\%, respectively, are $22 \%, 37 \%, 46 \%$ and $56 \%$ compared to the positive control.Based on this research, pineapple bark extract containing flavonoids, phenolics, saponins, triterpenoids, steroids and alkaloids. The results of this study can be concluded that the extract of pineapple skin Trichophyton mentaghrophyteswhich is characterized by the formation of inhibit
\end{abstract} zone.

Keywords: Trichophyton mentaghrophytes, peel pineapple, extract, ringworm, inhibition zone

\section{ABSTRAK}

Penyakit kurap pada kulit di sebabkan oleh jamur Trichophyton mentaghrophytes, obat-obatan yang biasanya digunakan adalah obat sintetik, obat sintetik dapat menimbulkan dampak negatif.Oleh karna itu, penelitian mengenai zat antijamur alami terus dilakukan yakni dengan penggunaan dari kulit nanas.Kulit nanas merupakan limbah hasil olahan industri nanas yaitu sisa dari daging dan buah yang mengandung senyawa metabolit sekunder yaitu flavonoid, fenolik, saponin, triterpenoid, steroid, dan alkaloid. Tujuan dari penelitian ini untuk menentukan kandungan senyawa metabolit sekunder yang terdapat dalam kulit nanas dan untuk megetahui daya hambat jamur Trichophyton mentaghrophytesdengan menggunakan metode experimental laboratory secara in vitro.Ekstrak kulit nanas dibuat dalam berbagai konsentrasi yaitu 10\%, 15\%, 20\%, dan $25 \%$, kemudian dilakukan uji daya hambat jamur Trichophyton mentaghrophytesdan diinkubasi suhu $25^{\circ} \mathrm{C}$ selama 5 hari. Berdasarkan hasil penelitian ekstrak kulit nanas didapatkan persentase uji daya hambat jamur Trichophyton mentaghrophytespada konsentrasi 10\%, 15\%, 20\%, dan 25\%, berturut-turut yaitu 10\%, 36\%, $58 \%$ dan $71 \%$ dibandingkan dengan kontrol positif.Berdasarkan hasil penelitian, ekstrak kulit nanas mengandung senyawa flavonoid, fenolik, saponin, triterpenoid, steroid, dan alkaloid.Hasil penelitian ini dapat disimpulkan bahwa ekstrak kulit nanas mampumenghambat jamur Trichophyton mentaghrophytesyang ditandai dengan terbentuknya zona hambat.

Kata Kunci: Trichophyton mentaghrophytes, ekstrak, kulit nanas, kurap, zona hambat 


\section{Pendahuluan}

Di Indonesia infeksi jamur masih cukup tinggi, salah satunya adalah tinea pedis. Penyakit ini disebabkan oleh Trichophyton mentagrophytes. Bentuk makroskopis Tricophyton mentagrophytes seperti tenunan lilin, berwarna putih kekuningan atau berwarna violet merah. Trichophyton mentagrophytes ini dapat menginfeksi kulit, kuku, rambut dan tidak kejaringanyang lebih dalam (Tan, 2016).

Obat-obatan yang sering digunakan untuk mengurangi infeksi jamur antara lain ketokonazol dan mikonazol. Penggunaan obat-obatan sintetik terkadang dapat menimbulkan rasa gatal jika diberikan dalam dosis tinggi (Brown, 2005). Pengobatan infeksi akibat Trichophyton mentaghrophytes dapat dilakukan secara tradiosional yang sifatnya murah dan mudah diperoleh. Penelitian Bayuaji dkk., (2012) menunjukkan bahwa ekstrak daun ketepeng cina (Senna alata L) memiliki aktivitas anti jamur pada konsentrasi 60\%, Uji tersebut dilakukan terhadap Trichophyton mentaghrophytes, hal ini disebabkan oleh kandung alkaloid, antrakuinon, flavonoid, saponin, tannin, terpenoid dan steroid.

Selanjutnya penelitian yang dilakukan oleh Hakim, (2009) menambahkan Ekstrak etanol rimpang kecombrang (Nicolaia speciose) memiliki aktivitas anti jamur pada konsentrasi 100 ppm dan 1000 ppm terhadap Trichophyton mentaghrophytes. Hal ini disebabkan oleh kandungan alkaloid, flavonoid, stroid, sapponin dan minyak atsiri.

Selain daun ketepeng cina (Senna alataL) dan rimpang kecombrang (Nicolaia speciosa) menurut Hatam dkk., (2013) bahwa kulit buah nanas juga memiliki senyawa yang sama yaitu fenolik dan flavonoid. Sedangkan penelitian Perveena dan Estherlydia (2014) menyatakan bahwa kulit buah nanas juga mengandung tannin, saponin dan steroid/triterpenoid. Kulit nanas merupakan limbah hasil pengolahan industri nanas, bagian yang tidak dipergunakan sehingga menjadi limbah di masyarakat (Sunarjono, 2010).

Kulit nanas yang mengandung berbagai macam senyawa metabolit sekunder mendorong peneliti untuk mengetahui apakah ekstrak kulit nanas (Ananas comosus L. Merr) mempunyai kemampuan dalam menghambat pertumbuhan Trichophyton mentagrophytes. Penelitian ini bertujuan untuk mengetahui besarnya zona hambat ekstrak kulit nanas dalam menghambat pertumbuhan Trichophyton mentagrophytes.

\section{Tinjauan Pustaka}

\subsection{Nanas}

Tanaman nanas (Ananas comosus L. Merr) termasuk famili Bromeliaceae ordo Poales, merupakan buah tropis yang berasal dari Amerika selatan. Buah nanas cukup popular di Indonesia. Rasanya yang manis menyegarkan digemari anak-anak maupun orang dewasa. Buah ini mengandung cukup banyak air. Kandungan gizi buah nanas sangat baik bagi kesehatan tubuh. Diantaranya vitamin A, vitamin C, fosfor, kalsium, kalium, protein, bromelin, natrium, zat besi, magnesium dan serat (Prasetio, 2015). Buah nanas (Ananas comosus L.Merr) dapat dilihat pada Gambar 1

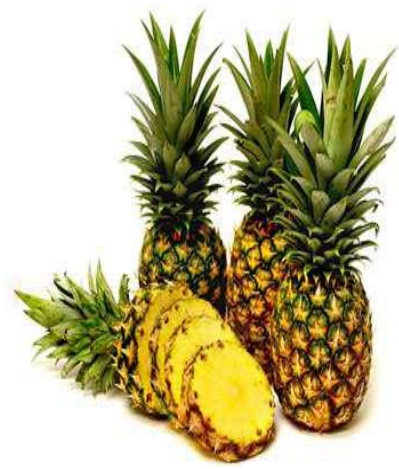

Gambar 1 Buah Nanas (Sumber: Winarti, 2013) 
Menurut National Center for Biotechnology Information (2017) tumbuhan nanas diklasifikasikan sebagai berikut :

$\begin{array}{ll}\text { Kingdom } & : \text { Viridiplantae } \\ \text { Filum } & : \text { Streptophyta } \\ \text { Class } & : \text { Liliopsida } \\ \text { Ordo } & : \text { Poales } \\ \text { Family } & : \text { Bromeliaceae } \\ \text { Genus } & : \text { Ananas } \\ \text { Spesies } & : \text { Ananas Comosus L. Merr }\end{array}$

\subsection{Kulit Nanas}

Kulit nanas merupakan limbah hasil olahan industri nanas yaitu sisa dari daging dan buah. Berbagai produk dari olahan nanas tentunya akan menyisakan limbah. Seringkali dijumpai dipasar-pasar, limbah kulit nanas ini kurang dimanfaatkan bahkan dibuang begitu saja di tempat sampah. Semakin lama kulit nanas dibiarkan menumpuk tentunya akan mencemari lingkungan terutama baunya yang tidak enak. Sangat disayangkan bila kulit nanas hanya menjadi pencemar lingkungan Prasetio, (2015). Menurut Ibrahim dan mutia, (2016) kulit nanas menganung senyama metabolit sekunder yaitu flavonoid, alkaloid, tannin, dan steroid Gambar kulit nanas dapat dilihat pada Gambar 2.
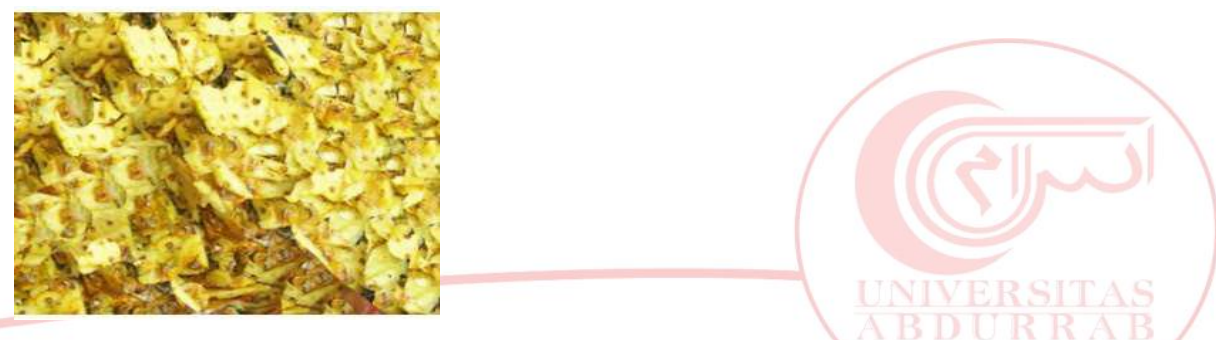

Gambar 2 Kulit nanas (Ananas comosus L. Merr) (Sumber: Ibrahim dan Mutia, 2016)

Tabel 1 Kandungan Gizi Kulit Buah Nanas

\begin{tabular}{ll}
\hline Kandungan gizi & Jumlah $(\%)$ \\
\hline Karbohidrat & 17,53 \\
Protein & 4,41 \\
Gula reduksi & 13,65 \\
Kadar air & 81,72 \\
Serat kasar & 20,87 \\
\hline
\end{tabular}

(Sumber: Ibrahim dan Mutia, 2016)

\subsection{Trichophyton mentagrophytes}

Jamur ini adalah salah satu penyebab terjadinya mikosis kutan, Mikosis kutan disebabkan oleh jamur yang hanya menginfeksi jaringan permukaan berkeratin. Keratin adalah protein utama dalam kulit, rambut dan kuku sebagai nutrisinya. Kelompok jamur yang menyebabakan mikosis kutan disebut dermatofita, yaitu genus Microsporum, Trichophyton dan Epydermaphyton dan infeksi oleh kelompok jamur ini sering disebut dermatofitosis (Jawetz dkk., 2005).
Kingdom : Fungi
Phylum : : Ascomycota
Class : Euascomycetes
Ordo : Onygenales
Family : Arthrodermataceae
Genus : :Trichophyton
Spesies : Trichophyton mentagrophytes 


\section{Metode Penelitian}

Jenis Penelitian yang digunakan adalah penelitian Eksperimental Laboratory secara in vitro, termasuk ke dalam penelitian tindakan (Action Research) yaitu penelitian yang dilakukan untuk mencari suatu pengetahuan praktis guna untuk memperbaiki suatu situasi atau keadaan kesehatan masyarakat (Notoatmodjo, 2012).

Penelitian ini dilaksanakan pada bulan November 2017 - Januari 2018 di Laboratorium Mikrobiologi dan Toksikologi Akademi Analis Kesahatan (AAK) Fajar

Populasi penelitian ini adalah Trichophytes mentaghrophytes. Sedangkan sampel yang digunakan dalam penelitian ini adalah strain Trichophytes mentaghrophytes yang diproleh dari Fakultas Kedokteran Universitas Riau.

Alat-alat yang digunakan dalam penelitian ini antara lain blender, vacuum rotary evaporator, yellow tip, blue tip, timbangan analitik, gelas ukur, gelas piala, erlemeyer, botol ekstrak, tabung reaksi, pipet tetes, pipet volumetrik, rak tabung, bola hisap, petri disk, ose cincin, aluminium foil, alu dan lumping.

Bahan yang digunakan dalam penelitian ini yaitu kulit nanas, larutan n-heksana, larutan etil asetat,larutan etanol, akuadest, Ekstrak kulit nanas(Ananas comosus. L Merr), mediaPotato Dextrose Agar (PDA), $\mathrm{NaCl}$ 0,9\%, Dymethyl Sufoxide (DMSO), ketokonazol dan Alkohol 70\%.

\section{Prosedur penelitan}

\section{Pembuatan Ekstrak Kulit Nanas}

Pembuatan ekstrak kulit nanas dilakukan secara bertingkat menggunakan tiga jenis pelarut yaitu pelarut $n$ heksana (pelarut non-polar), etil asetat (pelarut semi-polar), dan etanol (pelarut polar) dengan tujuan untuk mengetahui senyawa yang terkandung pada masing-masing pelarut tersebut. Dalam buku Farmakope Indonesia (1984) dinyatakan cara maserasi yaitu Siapkan kulit nanas dan di potong menjadi potongan kecil. Kulit nanas tersebut dikeringkan menggunakan oven suhu $40^{\circ} \mathrm{C}$ selama $48 \mathrm{jam}$. Kulit nanas yang sudah kering dihaluskan dan di timbang sebanyak 400 gram, kemudian dilakukan proses maserasi dengan menambahkan pelarut $\mathrm{n}$ heksana sebanyak $800 \mathrm{~mL}$ dan biarkan selama 24 jam dalam keadaan tertutup. Setelah 24 jam larutan di saring dan filtratnya di pekatkan dengan menggunakan vacum rotary evaporator sehingga didapatkan ekstrak nheksana. Proses maserasi kedua dilakukan dengan menggunakan residu dari maserasi pertama. Residu tersebut ditambahkan $800 \mathrm{~mL}$ pelarut etil asetat dan dibiarkan selama 24 jam dalam keadaan tertutup. Setelah 24 jam larutan di saring dan filtratnya di pekatkan dengan menggunakan vacum rotary evaporator sehingga didapatkan ekstrak etil asetat. Proses maserasi ketiga dilakukan dengan menggunakan residu dari maserasi kedua. Residu tersebut ditambahkan $800 \mathrm{~mL}$ pelarut etanol $96 \%$ dan dibiarkan selama 24 jam dalam keadaan tertutup. Setelah 24 jam larutan di saring dan filtratnya di pekatkan dengan menggunakan vacum rotary evaporator sehingga didapatkan ekstrak etanol. Proses ini menghasilkan tiga ekstrak kulit nanas yaitu ekstrak n-heksana, ekstrak etil asetat, dan ekstrak etanol.

\section{Uji Fitokimia}

Sebanyak 5 gram sampel ekstrak kulit nanas ditambahkan masing-masing $5 \mathrm{~mL}$ air suling dan kloroform lalu dikocok kuat dan dibiarkan selama 8 menit sampai terbentuk dua lapisan. Lapisan air ekstrak kulit nanas digunakan untuk uji senyawa flavonoid, fenolik, dan saponin. Lapisan kloroform ekstrak kulit nanas digunakan untuk uji senyawa triterpenoid, dan steroid, sedangkan untuk uji alkaloid memiliki prosedur tersendiri (Harborne, 1987).

\section{Uji Flavonoid}

Beberapa tetes lapisan air ekstrak kulit nanas dimasukkan pada plat tetes lalu tambahkan $1-2$ butir logam magnesium dan beberapa tetes asam klorida pekat. Terbentuknya warna jingga, merah muda sampai merah menandakan adanya senyawa flavonoid.

\section{Uji Fenolik}

Beberapa tetes lapisan air ekstrak kulit nanas dimasukkan pada plat tetes ditambah $1-2$ tetes larutan besi (III) klorida $1 \%$. Bila terbentuk warna biru/ungu, menandakan adanya senyawa fenolik. 


\section{Uji Saponin}

Lapisan air ekstrak kulit nanas dimasukkan kedalam tabung reaksi lalu dikoocok. Apabila terbentuk busa yang bertahan selama 5 menit, menandakan positif adanya saponin.

\section{Uji Steroid}

Lapisan kloroform ekstrak kulit nanas disaring melalui pipet yang diujungnya diberi kapas. Hasil saringan dipipet $2-3$ tetes dan dibiarkan mengering pada plat tetes. Setelah kering ditambahkan pereaksi Liebermann-Burchard (2 tetes asam asetat anhidrat dan 1 tetes asam sulfat pekat). Terbentuknya warna merah jingga menandakan bahwa positif warna hijau-biru adanya steroid.

\section{Uji Alkaloid}

Pengujian adanya senyawa alkaloid, digunakan metode Culvenor-Fizgerald. 2 mg ekstrak ditambahkan $10 \mathrm{~mL}$ larutan kloroform beramoniak $0,05 \mathrm{M}$, diaduk kemudian disaring dan dimasukkan ke dalam tabung reaksi. Kedalam tabung reaksi tersebut ditambahkan $1 \mathrm{~mL}$ asam sulfat $2 \mathrm{~N}$, dikocok selama 2 menit dan dibiarkan hingga terbentuk dua lapisan dan terjadi pemisahan. Lapisan asam (bagian atas) diambil dan ditambahkan $1-2$ tetes pereaksi Mayer atau pereaksi Dragendorff, terbentuknya endapan putih dengan pereaksi Mayer atau warna merah dengan pereaksi Dragendorff menunjukkan hasil yang positif untuk alkaloid.

\section{Uji Tannin}

Ekstrak kulit nanas ditambah dengan $\mathrm{FeCl}_{3} 1 \%$. Apabila larutan tersebut berubah warna menjadi hijau kehitaman atau biru tua maka ekstrak tersebut mengandung tannin (Rita, 2015).

\section{Uji daya hambat ekstrak kulit nanas terhadap jamur Trichophytone mentaghrophytes.}

Alawiyah dkk., (2016) menyatakan dalam pembuatan suspensi jamur, pertama siapkan alat dan bahan untuk penelitian, sterilisasi alat dan media yang akan digunakan, alat yang terbuat dari gelas disterilisasi didalam oven dan media yang sudah dilarutkan disterilisasi didalam autoclave. Kemudian ambil 1 ose koloni, masukkan kedalam tabung reaksi berisi $1 \mathrm{~mL} \mathrm{NaCl} 0.9 \%$ yang telah disterilisasi pada autoclave, bandingkan dengan Mc farland 1\%. Selanjutnya buat media Potato Dextrose Agar dalam $100 \mathrm{~mL}$ aquadest kemudian larutkan dalam erlenmeyer. Lalu tambahkan $1 \mathrm{~mL}$ antibiotik kloramphenicol kedalam erlenmeyer tersebut. Tuang suspensi jamur yang telah dibuat kedalam erlenmeyer dan homogenkan. Masukkan larutan tersebut kedalam petridisk yang telah disterilisasi. Biarkan dingin dan membeku. Ambil disk kosong steril dan letakkan disk tersebut pada plat, kemudian pipet masing-masing ekstrak kulit nanas konsentrasi 10\%, 15\%, 20\%, dan $25 \%$ sebanyak $10 \mu \mathrm{l}$ dan letakkan pada disk tersebut. Untuk kontrol Positif, Pipet $10 \mu \mathrm{l}$ antibiotik Ketokonazol yang sudah dilarutkan letakkan pada permukaan disk, lalu untuk kontrol negatif pipet $10 \mu \mathrm{l}$ DMSO dan letakkan pada permukaaan disk. Masukkan disk yang sudah berisi larutan tersebut pada permukaan agar PDA menggunakan pinset. Beri tanda label pada masing-masing cawan petri dan inkubasi pada suhu $25^{\circ} \mathrm{C}$ selama 5 hari di dalam suhu kamar.

\section{Analisis Data}

Hasil pengujian daya hambat Trichophyton mentaghrophytes menggunakan ekstrak kulit nanas dengan mengukur besarnya zona dari semua konsentrasi. Selanjutnya data yang diperoleh akan disajikan dalam bentuk tabel dan hasil percobaan di bahas secara deskriptif.

\section{Hasil Percobaan}

\section{Identifikasi Senyawa Fitokimia}

Hasil ekstraksi kulit nanas dari pelarut n-heksana, etil asetat, dan etanol dilakukan uji secara kualitatif untuk mengetahui kandungan senyawa metabolit sekunder yang ada di dalam ekstrak tersebut.Hasil identifikasi kandungan senyawa fitokimia dari ekstrak kulit nanas dapat dilihat pada Tabel 2. 
Tabel 2. dentifikasi Fitokimia Ekstrak Kulit Nanas

\begin{tabular}{ll}
\hline Senyawa & Ekstrak \\
\cline { 2 - 3 } & Keterangan \\
\hline
\end{tabular}

Flavonoid

$(-) \quad(-) \quad(+)$

(+) (+) berwarna jingga sampai merah

(-) tidak terbentuk warna jingga

Fenolik

$(-)$

$(-)$

$(-)$

(+) berwarna biru atau ungu

(-) tidak terbentuk warna biru atau ungu

$\begin{array}{llll}\text { Saponin } & (-) & (+) & (+)\end{array}$

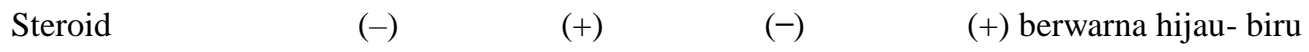

(-) tidak terbentuk warna hijau- biru

Alkaloid

$(-)$

$(+)$

$(-)$

(+) endapan putih

-Reagen Mayer

-Reagen Dragendorf

$(-)$

$(-)$

$(-)$

(-) tidak terbentuk endapan putih

(+) endapan merah

(-) tidak terbentuk endapan merah

$(-)$

Tannin
$(+)$

(+)

(+) berwarna hijauke hitaman

(-) tidak terbentuk warna hijau kehitaman

Hasil identifikasi fitokimia ekstrak kulit nanas, menunjukkan ekstrak n-heksana bahwa tidak mengandung senyawa metabolit sekunder, ekstrak etil asetat mengandung senyawa stroid, alkaloid dan tannin, sedangkan ekstrak etanol mengandung senyawa flavonoid,alkaloid dan tannin.

Uji Daya Hambat Ekstrak Etanol Kulit Nanas Menggunakan Trichophyton mentaghrophytes

Berdasarkan hasil penelitian zona hambat ekstrak etanol kulit nanas dalam pertumbuhan Trichophyton mentaghrophytes diperoleh data sebagai berikut dapat dilihat pada Tabel 3 
Tabel 3. Diameter Zona Hambat Ekstrak Etanol Kulit Nanas Menggunakan Trichophyton mentaghrophytes

\begin{tabular}{|c|c|c|c|c|c|c|c|}
\hline $\begin{array}{l}\text { Ekstrak Kulit } \\
\text { Nanas \% }\end{array}$ & $\begin{array}{l}\text { Ulangan } \\
(\mathrm{mm})\end{array}$ & I & $\begin{array}{ll}\begin{array}{l}\text { Ulangan } \\
(\mathrm{mm})\end{array} & \text { II }\end{array}$ & $\begin{array}{l}\text { Ulangan } \\
(\mathrm{mm})\end{array}$ & III & Rata rata $(\mathrm{mm})$ & $\begin{array}{l}\text { Persentase } \\
(\%)\end{array}$ \\
\hline 10 & 1,22 & & 0,96 & 0,94 & & 1,04 & 10 \\
\hline 15 & 1,43 & & 1,72 & 1,47 & & 3,74 & 36 \\
\hline 20 & 2,69 & & 2,73 & 1,67 & & 5,97 & 58 \\
\hline 25 & 3,83 & & 2,87 & 1,89 & & 7,33 & 71 \\
\hline$(+)$ & 10,97 & & 9,89 & 9,92 & & 10,26 & 100 \\
\hline$(-)$ & $(-)$ & & $(-)$ & $(-)$ & & $(-)$ & $(-)$ \\
\hline
\end{tabular}

Keterangan : *Diameter belum dikurangi dengan diameter disk $6(\mathrm{~mm})$, **Persentase didapat dari rata-rata zona hambat yang dibandingkan dengan kontrol positif.

Berdasarkan tabel 3 diatas dapat dilihat bahwa ekstrak kulit nanas mampu menghambat pertumbuhan jamur Trichophyton mentaghrophytes. Besarnya kemampuan penghambatan ekstrak berbeda-beda sesuai dengan tingkatan konsentrasi yang digunakan.

Diameter zona hambat yang terendah terdapat pada konsentrasi $10 \%$ dengan nilai rata rata $1.04 \mathrm{~mm}$ dan tertinggi pada kosentrasi $25 \%$ dengan nilai rata-rata $7.33 \mathrm{~mm}$. Pada kontrol positif (ketokonazol) menghasilkan diameter zona hambat $10,26 \mathrm{~mm}$, sedangkan pada kontrol negatif (DMSO) tidak menghasilkan diameter zona hambat.

\section{Pembahasan}

Uji fitokimia dilakukan untuk mengetahui kandungan senyawa metabolit sekunder. Hasil dari uji fitokimia menunjukanekstrak n-heksana bahwa tidak mengandung senyawa metabolit sekunder, ekstrak etil asetat mengandung senyawa stroid, alkaloid dan tannin, sedangkan ekstrak etanol ditemukan senyawa flavonoid, alkaloid dan tannin. Senyawa metabolit sekunder flavonoid, fenolik saponin, alkaloid, tannin, stroid dan polifenol yang terkandung didalam bahan alami ektrak kulit durian (Durio zibethinus L), akar tanaman bama (Plumbago zeylanica) dan daun gendrarussa (vulgaris Ness). Senyawa tersebut merupakan senyawasenyawayang dapat menghambat pertumbuhan Trichophyton mentaghrophytes (Juariah dan Wahyuni (2017); Karta dan Burhannuddin (2017); Mustikawati, (2010)).

Agrawal, (2012) menyatakan adanya kandungan senyawa flavonoid didalam ekstrak etanol kulit nanas memberikan kemampuan sebagai antijamur. Mekanisme kerja flavonoid dalam menghambat pertumbuhan jamur yakni dengan menyebabkan gangguan permeabilitas membran sel jamur. Gugus hidroksil yang terdapat pada senyawa flavonoid menyebabkan perubahan komponen organik dan transport nutrisi yang akhirnya akan mengakibatkan timbulnya efek toksik terhadap jamur. (Freiesleben dan Jager, 2014) flavonoid berkerja sebagai antijamur dengan melakukan penghambatan transpor elektron mitokondria yang mengakibatkan pengurangan potensial membran mitokondria. Penghambatan (inhibisi) dapat terjadi melalui penghambatan proton dalam rantai pernapasan yang menyebabakan penurunan produksi ATP dan kematian sel jamur sel berikutnya

Watson dan Preedy, (2007) kandungan tannin pada ekstrak etanol kulit nanas juga memberikan kemampuan sebagai antijamur. Mekanisme antijamur yang dimiliki tannin yaitu kemampuannya menghambat sintesis kitin yang digunakan untuk pembentukan dinding sel pada jamur dan merusak membran sel sehingga pertumbuhan sel jamur terhambat. Tannin merupakan senyawa yang bersifat lipofilik sehingga mudah terikat pada dinding sel dan mengakibatkan kerusakan dinding sel tersebut. 
Menurut khusnul., dkk (2017) senyawa metabolit sekunder lain yang terkandung didalam ekstrak etanol kulit nanas yaitu alkaloid yang berfungsi sebagai perusak membran sel. Mekanisme anti jamur yang dimiliki alkaloid yaitu dapat menghambat sintesis asam nukleat dan mempengaruhi ergostrol pada jamur. Mekanisme antijamur yang dimiliki stroid memiliki aktifitas antijamur dengan cara mempengaruhi permeabilitas membran sel yang akhirnya dapat menyebabkan membran sel lisis.

Berdasarkan hasil pengujian dari tiga ekstrak tersebut, ekstrak kulit nanas yang mampu untuk membentuk zona hambat adalah ektrak etanol kulit nanas, sehingga pengujian daya hambat dilakukan menggunakan ekstrak etanol kulit nanas. Berdasarkan hasil penelitian yang dilakukan, ekstrak etanol kulit nanas (Ananas comosus L. Merr) dengan konsentrasi 10\%, 15\%, 20\% dan 25\% dapat menghambat pertumbuhan Trichophyton mentaghrophytes dengan persentase zona hambat secara berturut-turut 32\%, 36\%, $58 \%$ dan $71 \%$. Hal yang sama dinyatakan oleh Gholib, (2009) bahwa hasil dari pengujian menunjukan ekstrak kencur (Kaempferia galangal L.) pada konsentrasi 20\%, 30\%, 40\% dan 50\% dapat menghambat Trichophyton mentaghrophytes dengan persentase zona hambat 28\%, 35\%, 36\% dan 41\% dibandingkan dengan zona hambat kontrol positif. Terjadinya variasi dari hasil zona hambat ekstrak etanol kulit nanas terhadap Trichophyton mentaghrophytes dikarenakan adanya konsentrasi senyawa metabolit sekunder yang terkandung didalam ekstrak etanol kulit nanas. Hasil penelitian menyatakan semakin besar konsentrasi ektrak maka semakin besar juga daya aktifnya. Konsentrasi yang lebih tinggi akan mampu merusak dan menghambat pertumbuhan jamur lebih maksimal.

Hasil dari uji daya hambat Trichophyton mentaghrophytes konsentrasi 25\% memiliki persentase 71\%. Hal ini menunjukan bahwa kemampuan ekstrak etanol kulit nanas memiliki kemampuan dibawah kontrol positif yang menunjukan diameter yang terbentuk mencapai 100. Kontrol positif yang digunakan adalah ketokonazol. Ketokonazol sering digunakan sebagai pengobatan terhadap pengobatan/Trichophyton mentaghrophytes. Mekanisme penghambatan pada ketolonazol yaitu dengan menghasilkan kadar plasma yang cukup untuk menekan aktifitas berbagai jenis jamur, melalui biosintesis ergosterol dalam sel jamur dengan menghambaat enzim P450 sitokrom, menimbulkan ketidakteraturan membran sitoplasma jamur dengan cara mengubah permeabilitas membran dan mengubah fungsi membran dalam proses pengangkutan senyawasenyawa esssensial yang dapat menyebabkan ketidak seimbangan metabolit sehingga mengganggu sintetis ergostrol yang merupakan komponen penting dari membran sel jamur (Tan dan Raharja, 1978) sedangkan kontrol negatif menggunakan pelarut.

\section{Kesimpulan}

Berdasarkan hasil penelitian tentang uji daya hambat Trichophyton mentaghrphytes menggunakan ekstrak kulit nanas (Ananas comosus L. Merr) dapat disimpulkan :

1. Senyawa metabolit sekunder yang terdapat pada ekstrak kulit nanas yaitu senyawa flavonoid,alkaloid dan tannin.

2. Zona hambat Trichophyton mentaghrophytes setelah pemberian ekstrak etanol kulit nanas yaitu pada konsentrasi $10 \%, 15 \% .20 \%$ dan $25 \%$ dengan persentase zona hambat secara berturut-turut $10 \%, 36 \%$, $58 \%$ dan $71 \%$.

\section{REFERENSI}

1. Agrawal, J. D., 2010. Pharmacological Activities of Flavonoids : A Review. International Journal of PharmacologicalSciences of an Nanotechnology. 4(2), 1394-1398.

2. Alawiyah, T., Khotimah, S., dan Mulyadi, A. 2016. Aktivitas Anti Jamur Ekstrak Teripang Darah (Holothuria Atra Jeager) Terhadap Pertumbuhan Jamur Malassezia Furfur Penyebab Panu. Jurnal Protobiont. Volume 5 (1): Halaman 59-67.

3. Bayuaji, S. T., Astuti, Y. I., Dhiani, A. B. (2012). Aktifitas antifungi daun ketapang cina (senna alate L) terhadap Trichophyton mentaghrophytes. Skripsi. Fakultas Farmasi, Muhammadiyah Purwokerto. Purwokerto.

4. Brown, G. R. 2005.Dermatologi. Ed 8. Erlangga. Jakarta. 
5. Freiesleban SH, Jager AK. 2014. Correlation between Plant Secondary Metabolites and Their Antifungal Mechanismms A Reviw, Med Aromat Plnts 3:154

6. Hakim, A. R. (2009). Uji potensi Antifungi Ekstrak Etanol rimpang kecombrang (Nicolaia specisa Horan) terhadap Trichophyton mentaghrophytes dan Trichophyton rubrum. Skripsi pada fakultas Kedokteran dan Ilmu Kesehatan. Universitas islma Negeri Syarif Hidayatullah Jakarta.

7. Harborne, J. B. 1987. Metode Fitokimia Penuntun Cara Modern Menganalisis Tumbuhan. Penerbit Institut Teknologi Bandung. Bandung.

8. Hatam, S. F., Suryanto, E., dan Abidjulu, J. 2013. Aktivitas Antioksidan Dari Ekstrak Kulit Nanas (Ananas comosus L. Merr). Jurnal Ilmiah Farmasi. Volume 2(01): Halaman 8-11.

9. Juariah, S., dan Wahyuni, S., 2017. Efektifitas Kulit Durian (Durio zibethinus L) Sebagai Penghambat Pertumbuhan Tichophyton mentagrophyes.

10. Ibrahim, W., dan Mutia, R. 2016. Penggunaan Kulit Nanas Fermentasi Dalam Ransum Yang Mengandung Gulma Berkhasiat Obat Terhadap Konsumsi Nutrient Ayam Broiler. Jurnal Agripet. Volume 16(2): Halaman 76-82.

11. Jawetz dkk., 2005).

12. Karta, W., dan Burhannuddin 2017. Uji Aktivitas Antijamur Ektrak Akar Tanaman Bama (Plumbago zeylanica) Terhadap Pertumbuhan Jamur Trichophyton mentaghrophytes Penebab Kurap Pada Kulit. Jurnal Analis Kesehatan, Poltekkes Denpasar.

13. Khusnul., Hindana, R., Kusmariani., W. Uji Evektifitas Ekstrak Etanol Rimpang Lengkuas (Alpinia galangal L) Terhadap Pertumbuhan Trichophyton rubrum Secara In Vivo. Program Studi DIII Analis Kesehatan Sekolah Tinggi Ilmu Kesehatan Bakti Tunas Husada Tasikmalay.

14. Mustikawati, I., isolasi dan identifikasi senyawa golongan alkaloid dan tannin dari daun gendarussa (vulgaris Ness). Tesis. Digital Library Universitas Airlangga.

15. National Center for Biotechnology Information. $2017 . \quad$ Taxonomy. https://www.ncbi.nlm.nih.gov/Taxonomy/Browser/wwwtax.cgi?id=4615

16. Notoadmojo, S. 2012. Metodologi Penelitian Kesehatan. Rineka Cipta. Jakarta.

17. Prasetio, B. 2015. Budidaya Tanaman Buah dalam Pot. Lili publisher. Yogyakarta.

18. Praveena, J., dan Estherlydia, D. 2014. Comparative study of phytochemical screening and antioxodant capacities of vinegar made from peel and fruit of pineapple (Ananas comosus L. Merr). International Journal of Pharma and Biosciences. Volume 5(4): Halaman 394-403.

19. Sunarjono, H. 2010. Berkebun 21 Jenis Tanaman Buah. Penebar Swadaya. Jakarta.

20. Tan, T. S. 2016. Ilmu Penyakit Kulit dan Kelamin. CV. Sagung seto .Jakarta.

21. Tan H. T., dan Rahardja. K. 1978. Obat-obat Penting Khasiat Penggunaan dan Efek-efek Sampingnya.. Edisi kelima. PT. Elex Media Komputindo Kelompok Gamedia. Jakarta.

22. Watson, R. R. dan Preedy, V, R., 2007. Bioactive food in promating health :probioties and prebioties Academic Press. USA.

23. Winarti. 2013. Pemanfaatan Limbah Kulit Nanas (Ananas comosus L. Merr) Untuk Pembuatan Pupuk Organik Cair. Skripsi. Politeknik Pertanian Samarinda. Samarinda. 